\title{
RECENT DEVELOPMENTS FOR STAPHYLOCOCCUS AUREUS VACCINES: CLINICAL AND BASIC SCIENCE CHALLENGES
}

\author{
R.A. Proctor ${ }^{1 *}$ \\ ${ }^{1}$ University of Wisconsin - Medical Microbiology/Immunology 835 Asa Gray, Ann Arbor, Michigan 48105, USA
}

\begin{abstract}
Bacterial vaccines have made dramatic impacts upon morbidity and mortality caused by a number of common pathogens, but a vaccine to prevent Staphylococcus aureus infections has proven to be illusive. With successful bacterial vaccines, the organisms are all part of the transient flora, whereas, $S$. aureus is part of the normal human flora. This means that $S$. aureus has had a prolonged time to adapt to the host milieu and its defences. The failure of several staphylococcal antigens to protect humans from infection in vaccine clinical trials using active or passive immunisation has stimulated a re-examination of the fundamental assumptions about staphylococcal immunity in humans $v s$. animals, especially rodents. This has spurred an active debate about the appropriate models for vaccine development and an examination of our current understanding of the protective immunity in humans. A major factor in the development of previous bacterial vaccines was a biomarker that predicted human protection, e.g., antibodies to tetanus toxoid or to pneumococcal polysaccharide. While antibodies against a number of staphylococcal antigens have proven to be an excellent biomarker for protection in rodents, these have not been translated to human infections. Thus, while much work remains, there is a growing consensus that T-cell immunity plays an important role in protecting humans. Moreover, the presence of anti-staphylococcal toxin antibodies correlates with reduced disease severity in humans. The most important recent advances concerning potential biomarkers, and the role of pre-existing immune status of vaccines in vaccine-associated mortality are considered in this review.
\end{abstract}

Keywords: Staphylococcus aureus, immunity, Th17, clinical trials, vaccine.

*Address for correspondence:

Professor Emeritus Richard A. Proctor, M.D.

Medical Microbiology/Immunology and Medicine

University of Wisconsin School of Medicine and Public

Health

835 Asa Gray, Ann Arbor, MI 48105, USA

Telephone number: (734) 780-7703

Email: rap@wisc.edu

\section{Introduction}

The epidemiology of $S$. aureus establishes a need for a vaccine. $S$. aureus is the number one cause for children requiring hospitalisation and surgery, and the leading cause of bacteraemia in people $>65$ years old (Proctor 2012a; Proctor 2012b). Another recent review (Tong et al., 2015) notes the impressive rates of $S$. aureus infections $/ 100,000$ population $/ \mathrm{y}$. Over that past decade bacteraemia rates $=20$ 38 , which jump to $>100$ for people over age $70 ; 1,960$ for HIV positive adults, and 66.5 for Blacks (as compared to Whites $=27.7$ ) When considering either MSSA or MRSA, there is a $25 \% 12$-week mortality in cardiac device infections and a 7-21\% mortality with intravascular catheter blood stream infections (Tong et al., 2015). The rates of invasive $S$. aureus infections are comparable to the pre-vaccine rates for Haemophilus influenzae (David and Daum, 2010; Millar et al., 2005). With skin and soft tissue infections, the rates for patients coming from community or basic training recruits range from $0.35 / 1000$ to $4 / 1000$ per year (Liu et al., 2008; Morrison-Rodriguez et al., 2010). A large multi-city study in the USA established a mortality rate of 18,650 MRSA deaths/year in the USA (Klevens et al., 2007). Finally, staphylococci are the most frequent pathogen involved in joint infections (Fisher et al., 2015; Kapadia et al., 2015; Lin et al., 2015; Parvizi et al. 2015). Therefore, there is clearly a need for a vaccine to protect against staphylococcal infections.

When considering vaccines, there are different levels of protective efficacy. The highest level would be prevention of infection. The next level would be reduced mortality. The lowest barrier would be reduced severity. Clearly, the last two levels are often directly related. A particular challenge comes with implant infections as the presence of biomaterials dramatically reduces the inoculum needed to establish an infection. This was first demonstrated in humans when Elek showed that the inoculum was reduced by at least $10^{5}$ fold when a suture was placed in the wound as compared to subcutaneous inoculation into skin (Elek and Conen, 1957). The presence of a foreign body also increases the difficulty in treating with antibiotics as biofilms of organisms show resistance even when the bacteria are susceptible in the microbiology laboratory (reviewed in McCarthy et al., 2015).

When considering bacterial vaccines, all successful vaccines have been developed when a biomarker for protective immunity was established. For example, anticapsular antibody against Streptococcus pneumoniae and anti-toxin antibody against tetanus toxoid correlated directly with protection against human S. pneumoniae and 
Clostridium tetani. Much of the difficulty in developing a preventive $S$. aureus vaccine stems from the fact that biomarker(s) for human protective immunity are unknown (Fowler and Proctor, 2014). In contrast, we do know that anti-toxin antibodies have been associated with reduced severity of human infections (Fowler and Proctor 2014; Fritz et al., 2013; Rasigade et al., 2011; Spalding et al., 2012). With $90 \%$ effectiveness for anti-toxin antibodies, one would anticipate that differences between controls and immunised to be achieved with 300 subjects in each group (Aman and Adhikari, 2014). Finally, another challenge for producing a $S$. aureus vaccine has been the fact that $S$. aureus produce many diseases and the strains of bacteria producing those diseases are dissimilar in terms of virulence factors (Laabei et al., 2015; Lowy, 1998). Hence, one could reasonably ask which $S$. aureus disease does one want to address rather than trying to address all infections? As the goal of this review is to consider the role for vaccines in implant infections, it will focus upon the prevention of disease, and the challenges for achieving this goal.

\section{Completed clinical trials}

What have we learned from the many clinical trials of various vaccine candidate antigens? To date, all of the clinical vaccine trials have been aimed at preventing or treating S. aureus diseases (Proctor 2012a; Proctor 2012b). Detailed reviews of the clinical trials have recently been reviewed and specifics will not be repeated in this article (Fowler and Proctor, 2014). Both passive and active immunisation has been tried (Fowler and Proctor, 2014; Jansen et al., 2013). The clinical trials have been based upon protective efficacy in animals, usually mice, and the immune marker has been opsonophagocytic antibody
(Fowler and Proctor, 2014; Jansen et al., 2013; Proctor, 2012a; Proctor, 2012b). All of the active immunisations showed increases in opsonophagocytic antibodies in human volunteers, as well as in subjects in the clinical trials. Nevertheless, all clinical trials have failed, despite strong protective responses in animals (Fowler and Proctor, 2014; Proctor 2012a; Proctor 2012b).

Developing a vaccine that prevents implant infections has been a goal for vaccine production (Montanaro, 2011). This might be accomplished by reducing adhesion and/or biofilm formation to the foreign body, and this has been tested against a small number of antigens within some of the clinical vaccine trials wherein anti-ClfA, anti-SdrG, anti-capsular polysaccharide (types 5 and 8) were tested using either active or passive immunisation (DeJonge et al., 2007; Rupp et al., 2007; Shinefield et al.. 2002; Weems et al., 2006). None of these antigens have proven successful in human vaccine trials. However, an anti-alpha toxin antibody (Brady et al., 2013), anti-glucosaminidase antibody (Varrone et al., 2014) and accumulation protein antibody (Yan et al., 2014) have shown efficacy in murine models. Perhaps one of these new antigens will prove successful. While complete prevention is a very high hurdle, the strategy to combine antibodies with antibiotics may be efficacious as the antibodies will reduce biofilm and clumping of bacteria and thereby enhance antibiotic activity.

\section{On-going clinical human vaccine trials}

Some comments can be made about the five vaccine trials and the human host response to invasive $S$. aureus infections where data are still pending (Table 1).

The Pfizer trial is examining protection from infections in patients undergoing lumbar spinal fusion. Except for

Table 1. Information from the clinical trials.gov web site (https://clinicaltrials.gov/ct2/results?term=staphylococcus\& Search=Search) searched for the term "staphylococcus" and from company web sites, e.g., GSK Pipeline report (see Web References). All of the trials have demonstrated the production of antibodies, and no safety concerns in the Phase I and II trials (where applicable) as reported by data at the web sites

\begin{tabular}{|l|l|l|l|}
\hline Company & Antigens & Phase & Comments \\
\hline Pfizer & ClfA, MntC, CP 5, CP8 & II (Lumbar surgery) & 3 of 4 Ags already tested before \\
\hline NovaDigm & $\begin{array}{l}\text { rAls3p-N (NDV-3) for } \\
\text { Ab and T cell responses }\end{array}$ & IIb & $\begin{array}{l}\text { Single, novel antigen for } \text { S. aureus and C. albicans } \\
\text { RVVC }\end{array}$ \\
\hline NABI/GSK & rLukS-PV, $\alpha$-toxin & I & $\begin{array}{l}\text { Secreted proteins; no longer listed in March 2015 } \\
\text { pipeline report }\end{array}$ \\
\hline GSK & Tetravalent & I & $\begin{array}{l}\text { Unknown antigens; no longer listed in March } 2015 \\
\text { pipeline report }\end{array}$ \\
\hline Novartis & 4 proteins & I & $\begin{array}{l}\text { Based upon opsonophagocytic Ab; no data are } \\
\text { available }\end{array}$ \\
\hline $\begin{array}{l}\text { Vaccine } \\
\text { Research Intl }\end{array}$ & Whole cell (SA75) & I & $\begin{array}{l}\text { Measured Ab against CAN, ClfA, FnBP, Eap; no } \\
\text { data provided on thefunction of the Abs }\end{array}$ \\
\hline
\end{tabular}

$\mathrm{Ab}=$ antibody; $\mathrm{Ag}=$ antigen; $\mathrm{rAlsp}-\mathrm{N}=$ recombinant $\mathrm{N}$ terminus of $C$. albicans protein; $\mathrm{CAN}=$ collagen binding protein; ClfA = clumping factor; $\mathrm{CP} 5$ and $\mathrm{CP} 8=$ capsular polysaccharide types 5 and 8; Eap = extracellular adhesion protein; $\mathrm{MntC}=$ manganese transport protein $\mathrm{C} ; \mathrm{rLukS}-\mathrm{PV}=$ a recombinant $\mathrm{PVL}=$ Panton-Valentine leukocidin; $\mathrm{RVVC}$ $=$ recurrent vulvovaginal candidiasis; Th17 $=\mathrm{T}$ helper 17 cell; $\mathrm{TLR}=$ toll-like receptor. These are surface antigens on $S$. aureus that are being developed as vaccine components. 
MntC, the other three antigens (Nissen et al., 2015) have been tested in other vaccine trials and failed. There are no study results posted on the web sites. However, a followup Phase III trial was just published on the types 5 and 8 capsular antigens as vaccine candidates wherein a second dose was added at 35 weeks for patients on haemodialysis, and this trial failed to show protection as well (Fattom et al., 2015). The NDV-3 trial sponsored by NovaDigm is using a novel recombinant protein from $C$. albicans that was found to provide cross protection against $S$. aureus infections that was mediated by Th17 cells in mice (Schmidt et al., 2012; Spellberg et al., 2008). The Phase I trial is followed up with a Phase II trial aimed at preventing recurrent vulvovaginal candidiasis. One assumes that clinical trials for $S$. aureus will be forthcoming, but none are yet scheduled. Two trials involving GSK antigens (rLukS-PV/ $\alpha$-toxin and a Tetravalent vaccine) have finished phase I, but the March 2015 pipeline report no longer has these trials listed as on going. Only the safety data from phase I have been released. A Novartis clinical trial using four proteins, which have not been specified, may also be on-going, but no data beyond the phase I trial are available. The basis for the Novartis trial is opsonophagocytic activity, whose limitations have been discussed above. Vaccine Research International is studying a whole cell vaccine, based upon $S$. aureus 75, and the data available report on antibodies directed against staphylococcal adhesins. There are no data provided about the functional activity of these antibodies, but the goals are prevention of infection; therefore, one assumes that the function would be prevention of colonisation. Finally, a NIAID-sponsored trial conducted through the University of Maryland started in 2009 and was completed in Sept 2014. The goals of this trial were to examine white blood cell responses using microarrays, Th17 activity, and TLRs responses. While this trial should provide human immune response data in invasive $S$. aureus infections, these muchneeded results have not yet been published.

\section{Conclusions from clinical trials}

Several conclusions may be drawn explaining the poor outcomes of the clinical trials. First, the protective immune response (opsonophagocytic antibodies) found in the animal models used to date have not predicted efficacy in humans. Second, excess mortality was seen in the V710 (anti-IsdB antigen) vaccinated and $S$. aureus infected group, which was associated with systemic inflammatory response and multi-organ failure (Fowler et al., 2013). A similar disturbing finding occurred with anti-type 5 and 8 pooled human anti-capsular antibodies (Altastaph), wherein there was a trend toward higher mortality in the vaccinated group ( $23 \% v s .11 \%, p=0.42)$ as well as more adverse events (95\% in Altastaph group) (Rupp et al., 2007). Third, anti-S. aureus antibodies are not a biomarker for protection against human $S$. aureus infections (Fowler and Proctor, 2014; Montgomery et al., 2014; SalgadoPabón and Schlievert, 2014; Verkaik et al., 2010). Fourth, $S$. aureus causes a very wide variety of diseases, and it may be asking too much for a single vaccine to prevent all of them as different strains of $S$. aureus have differing propensity for causing certain types of infections. Finally, $S$. aureus is a part of the normal flora and has evolved many mechanisms for thwarting the human immune response, especially opsonophagocytic processes (Bestebroer et al., 2010; Lu et al., 2014; Pauli et al., 2014; Serruto et al., 2010; Spaan et al., 2013; van Kessel et al., 2014). In these reviews, we see that $S$. aureus has essentially every step of the immune response blocked by its vast array of proteins. Examples include, inhibition of neutrophil attachment to endothelial cells by SSL-5, SSL-6 and Eap; inhibition of neutrophil interaction with chemoattractants by SSL-10, CHIPs, and FLIPr; blocking of antibody interactions with neutrophils by SSL-7, SSL-8, and protein A; and inhibition of complement by Ecb, SCIN, and CHIPS. A more complex vaccine approach might include neutralising several of the staphylococcal factors that inhibit the immune system as well as adding vaccine antigens.

In retrospect, the failure of opsonophagocytic antibodies to protect humans is not surprising. While opsonophagocytic antibodies are a clear biomarker for $H$. influenzae and $S$. pneumoniae, patients with agammaglobulinaemia (genetic or acquired complete lack of immunoglobulins) show no increase in the incidence of S. aureus infection (reviewed in Fowler and Proctor, 2014). Of course, neutralising antibodies to staphylococcal toxins have correlated with reduction in the severity of $S$. aureus infections (Fowler and Proctor, 2014; Salgado-Pabón and Schlievert, 2014), but these antibodies are less likely to prevent infections. Moreover, the use of rodent models for predicting human responses to staphylococcal infections for either protective efficacy (Proctor 2012a; Proctor 2012b; Salgado-Pabón and Schlievert, 2014) or human inflammatory responses to sepsis (Seok et al., 2013), have been poor.

A very recent review by (Pozzi et al., 2015) attempts to address the role of antibody and animal models in the design of staphylococcal vaccines. Unfortunately, this review contains major errors because of a lack of understanding of clinical medicine and basic epidemiology. In particular, there are major problems with the associations drawn between hypogammaglobulinaemia and the increased incidence of $S$. aureus infections. For example the authors fail to separate the occurrence of $S$. aureus pneumonia in some patients with XLA and an increased incidence. The rate of Staphylococcus sp. was not increased above background. Moreover, patients with disorders in their skin (atopic dermatitis, juvenile pityriasis rubra, etc.) have a failure of the barrier function of the skin; therefore, they have more $S$. aureus infections. This happens in all people with loss of barrier function and hypogammaglobulinaemia again is not the cause of the more frequent infections. Heavy colonisation with $S$. aureus is a risk factor for invasive $S$. aureus infections so skin barriers are important. In another paper cited in the (Pozzi et al., 2015) review, an IgG infusion used by (Castanet et al., 1994) was claimed to cause improvement of $S$. aureus folliculitis. This is a single anecdotal case. More importantly, this case report has multiple shortcomings. First, there is no description of the organism. Is it a heavy toxin producer? Production of leukocidins and haemolysin has been associated with more severe skin infections. Clearly, this and previous reviews 
have emphasised that neutralisation of toxins can reduce the severity of $S$. aureus disease (Proctor, 2012a; Proctor 2012b, Fowler and Proctor, 2014). However, anti-toxins have not yet been shown to prevent $S$. aureus infections. Second, as noted in the Castanet case report, people with these skin diseases have more viral and bacterial infections due to loss of barrier function of the skin. There were no viral cultures taken in this patient; therefore, the IVIG may have treated a concurrent viral infection, which then allowed clearing of the $S$. aureus infection. Third and most importantly, there was no testing of the patient's neutrophils in the presence and absence of the IVIG against the $S$. aureus isolated from the patient. Hence, the assertion that hypogammaglobulinaemia played a role in clearing the infection is simply speculation. Fourth, T-cell dysfunction has been reported with juvenile pityriasis rubra pilaris (Shvili et al., 1987), which might account for the cutaneous $S$. aureus infections. (Castanet et al., 1994) examined the numbers of T-cell subsets, but they did not test the function of the T cells. Fifth, the IVIG may have altered the skin disease thereby improving the barrier function, and it is noteworthy that no biopsy of the skin is reported after the IVIG therapy. In support of this idea is the fact that it took over 2 months for the IVIG to bring improvement to the $S$. aureus skin infections. If the IVIG were acting to improve opsonic activity in the patient, then the response should have been almost immediate (certainly within a week) rather than after two months. Thus, this single case was poorly studied and complicated because the patient continued to receive antibiotics; therefore, the impact of IgG cannot be linked directly to the clearance of $S$. aureus. Other statements are made about IgG infusions improving $S$. aureus infections, but these are non-referenced in the (Pozzi et al., 2015) review. Further attempts are made to implicate $\operatorname{IgG}$, for example, patients with chronic lymphocytic leukaemia (CLL) are mentioned, but these patients are often treated with agents that cause neutropaenia and with prednisone, which suppresses T-cell immunity. In addition, in the later stages of CLL there is often a decrease in cell-mediated immunity. The CLL data are not at all convincing that hypogammaglobulinaemia had anything to do with their S. aureus infections. Finally, "rheumatologic disorders" are thrown-in to support of hypogammaglobulinaemia as a cause of $S$. aureus infections, but there are clearly other immunological reasons for $S$. aureus infections in these patients, such as rheumatoid factor, that blocks neutrophil function; treatment with prednisone that depresses cellmediated immunity, and neutropaenia is frequent in a number of "rheumatologic disorders". In summary, the information in the (Pozzi et al., 2015) review is not at all convincing that hypogammaglobulinaemia plays any role in increasing the incidence of $S$. aureus infectious diseases.

Other arguments are made by (Pozzi et al., 2015) for the value of antibodies based upon animal models, but we have ample clinical data from the failed human clinical vaccine trials that these models do not predict success in humans. Another argument for antibodies being important is that people develop antibodies to staphylococcal antigens after S. aureus infections and after colonisation shortly following birth. This only shows that the patients had an immune response, which would involve T-cell immunity, but it does not establish antibodies are being protective. Finally, data for the protective effect of anti-toxin antibodies are provided, and these comments are in agreement with this and previous reviews as being valuable.

The (Pozzi et al., 2015) review continues with a very large amount of elegant murine immunology, which has not been shown to be relevant to human immune response against $S$. aureus. Demonstration that phagocyte subsets and lymphocyte clonal deletion are key elements in the failure of the staphylococcal vaccines would be a major step in developing a preventive $S$. aureus vaccine, but this will require considerable work to show that it has occurred in the failed human clinical vaccine trials or in a prospective clinical trial.

The lack of biomarkers and predictive animal models strongly makes the case for having more research into the human immune response before going ahead with more vaccine trials. What do we know about the human protective immune response against $S$. aureus?

\section{Human adaptive immunity against $S$. aureus}

A model showing the immune cells and cytokines involved in human adaptive immunity to $S$. aureus is provided in Fig. 1. This model does not show the plethora of staphylococcal extracellular factors used to thwart the actions of antibodies, complement, and phagocytes because these have been extensively recently reviewed (Bestebroer et al., 2010; Spaan et al., 2013; Serruto et al., 2010; van Kessel et al., 2014).

People with defects in cellular immunity have an increased incidence of $S$. aureus infections (CrumCianfione et al., 2009; Ishigame et al., 2009). Similarly, people with neutropaenia or defects in neutrophil function develop more $S$. aureus infections than normal people (Donabedian and Gallin, 1983; Ma et al., 2008; Minegishi et al., 2009; Quilty et al., 2009; White and Gallin, 1986) as neutrophils play a major role in killing invasive $S$. aureus (Kobayashi et al., 2010). Where do cellular immunity and neutrophil problems coincide? This occurs in people who have defects in Th17 cells because the Th17/IL-17 arm of the immune system is used to call in and to activate neutrophils at sites of $S$. aureus invasion (Ishigame et al., 2009; Ma et al., 2008; Minegishi et al., 2009). Moreover, Th17 activation also primes mucosal and skin surfaces to produce cationic antimicrobial peptides, which enhances the protective barrier against $S$. aureus invasion (Minegishi et al., 2009). Cytokines IL-6 activates Th17 while IL-10 reduces Th17 activation (Maródi et al., 2012; Puel et al., 2008). Phenol soluble modulins (PSMs) produced by $S$. aureus stimulate macrophages to produce more IL-10 (Schreiner et al., 2013), thereby down-regulating Th17 activation. Blockage of IL-6 with autoantibodies and increased levels of IL-10 are associated with more $S$. aureus infections in humans (Maródi et al., 2012; Puel et al., 2008). Very recently, IL-26, which is a downstream cytokine in the Th17 pathway, not only functions as a cytokine, but it also has antimicrobial peptide activity (Braum et al., 2012; Meller et al., 2015). Also recently, 
bone marrow dendritic cells and macrophages, which normally kill $S$. aureus, were found to be a safe haven for $S$. aureus strains that displayed high activity of the Agr quorum-sensing system (O'Keeffe et al., 2015). Finally, the staphyloccidal activity of dendritic cells is enhanced by vitamin $\mathrm{D}$ and patients that are vitamin $\mathrm{D}$ deficient are more likely to have more nasal carriage, skin infections, and more invasive infections (Olsen et al., 2012; Thomason et al., 2015; van der Does et al., 2014; Wang et al., 2015).

Some of the antibodies tested in clinical trials have aimed at staphylococcal adhesins (Fowler and Proctor, 2014; DeJonge et al., 2007; Weems et al., 2006). The antibodies must bind these ligands and prevent attachment to host tissues. While higher affinity monoclonal antibodies have been produced, they have failed in clinical trials in terms of preventing or treating infections (Bebbington and Yarranton, 2008). The affinity of $S$. aureus adhesins directly correlates with the development of invasive infection (Casillas-Ituarte et al., 2012; Lower et al., 2011); hence, this may have clinical relevance. One factor that may contribute to the failure of monoclonal antibodies to prevent infections is that $S$. aureus surface proteins have multiple binding sites with very high dissociation constants (Provenza et al., 2010; Ross et al., 2012); therefore, even relatively high affinity MAbs may not be able to compete with the staphylococcal adhesins for host proteins. Affinity constants of staphylococcal adhesins and toxins show a direct correlation with the production of human disease (Lower et al., 2011; Tkaczyk et al., 2012). This problem may be complicated by the observation that human and animal proteins do not bind staphylococcal adhesins identically (Foster et al., 2014). The situation is made more difficult when one considers that even preventing $99 \%$ of staphylococci binding to an implanted device may not prevent infection because of the relatively low inoculum needed to cause infection of foreign bodies (Elek and Conen, 1957). Thus, asking monoclonal antibodies to prevent infection by competing with adhesins is a tall order.

The clinical problem is different when this approach is applied to the neutralisation of staphylococcal toxins, wherein efficacy in animal models can be directly correlated with monoclonal antibody affinity (Tkaczyk et al., 2012) and levels of anti-toxin antibodies in humans correlate with reduced severity of infections (Foster et al., 2014). These anti-toxin antibody actions are summarised within a box in Fig. 1. In addition, antibody-staphylococcal interactions can also activate the IFN- $\gamma$ pathway for clearance of $S$. aureus in mouse models (Pancari et al., 2012). A model for $S$. aureus adaptive immunological responses in humans is shown (Fig. 1).

\section{Human Adaptive Immune Response to Staphylococcus aureus Infection}

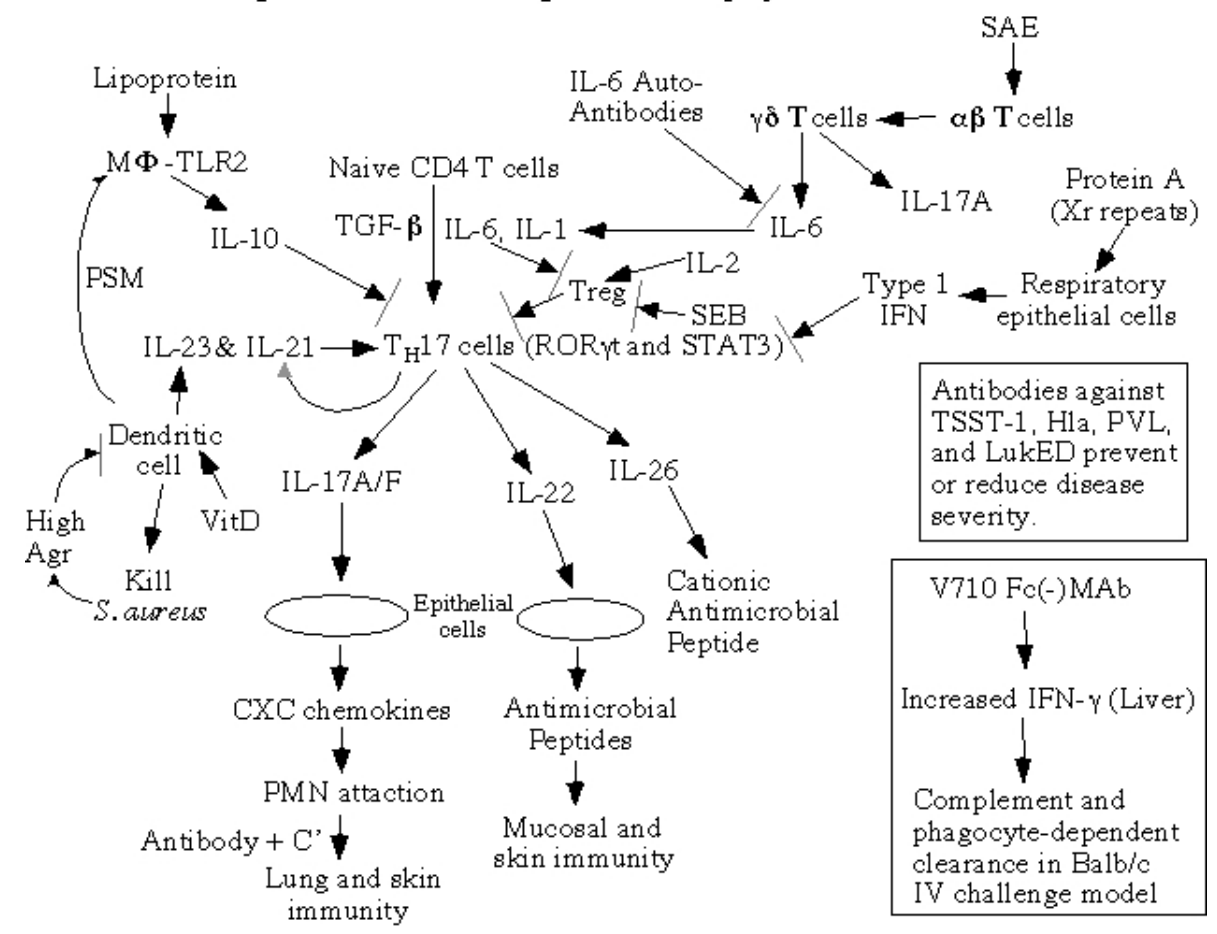

Fig. 1. A model for $S$. aureus adaptive immunological responses in humans. The exceptions are for SEB (staphylococcal enterotoxin B) wherein it interacts with regulatory T cells (Treg; CD4 ${ }^{+} \mathrm{Foxp} 3^{+}$) and V710 MAb in the liver, which is based upon murine data. For the most part, toxin responses are similar between human and animal model responses. Positive actions are indicated with arrows, whereas inhibitory responses are with blocked arrows. Abbreviations MФ macrophage; PSM, phenol-soluble modulins; IL, interleukin; TGF- $\beta$, transforming growth factor- $\beta$; Th17, T helper type 17 cells; mAb, monoclonal antibody; V710, IsdB (iron-regulated surface determinant) antigen used in Merck Vaccine trial; C', complement; SAE, S. aureus enterotoxin E; ROR $\gamma$ t, retinoid-related orphan receptor c; STAT3, signal transducer and activator of transcription 3; Hla, $\alpha$-toxin; TSST-1, toxic shock syndrome toxin-1; Luk, leucocidin; PVL, Panton-Valentine leucocidin (two component toxin made up of LukS-PV and LukF-PV); IFN- $\gamma$, interferon- $\gamma$; VitD = vitamin D. 


\section{Limitations and dangers of immune activation}

When considering activation of Th17 as the answer to $S$. aureus vaccine production, several cautions are needed. First, while the evidence for T cells and especially Th17 playing an important role in human immunity against $S$. aureus is gaining support (Kolata et al., 2015; Misstear et al., 2014; Montgomery et al., 2015), Th17 immunity has not been shown to be a biomarker for protection. Second, high levels of IL-10 and low levels of IL-1 and TNF- $\alpha$ have been associated with worse outcomes in bacteraemia, including S. aureus bacteraemia (Burke et al., 2013; Rose et al., S (2013a) [Biomarkers in Staphylococcus aureus bacteraemia predicting bacteraemia duration or patient mortality. ICAAC Abstract B-1432]; Rose et al., 2013b [Differential whole blood killing and IL-1 response in Staphylococcus aureus isolates from patients with persistent and rapidly cleared bacteraemia. ICAAC Abstract B-490]; van Dissel et al., 1998). These cytokines can be related to Th17, but whether or not these cytokines will serve as biomarkers still needs to be tested in clinical vaccine trials before being accepted as biomarkers for $S$. aureus immunity. Third, the duration of Th17 immunity may be relatively short. When our standard B. pertussis vaccine went from a whole-cell to a subunit vaccine, the protection also shifted from being antibody-dependent to Th17-mediated immunity (Dunne et al., 2010). The duration of immunity also changed from being very long-term with the whole cell vaccine to being relatively short-lived immunity with the acellular vaccine such that as children reach their early teenage years, they are developing whooping cough (Lavine et al., 2012; McGirr et al., 2015). There are no data about the duration of a Th17-based human immune response to $S$. aureus, but it might be equally short-lived, which would be fine for prevention of infections in ICU or implant surgeries, but it would not provide longer-term protection. Fourth, the IsdB antigen (V710 vaccine trial) did stimulate and protect by Th17, and not antibody-dependent, mechanisms (Joshi et al., 2012). However, patients receiving the V710 vaccine that developed invasive $S$. aureus infections unexpectedly showed an increased incidence of multi-organ failure and death (Fowler et al., 2013). Examination of cytokines in the sera from the twelve V710 recipients who died were compared to the single death amongst the, thirteen placebo recipients (McNeely et al., 2014). All twelve vaccines had undetectable levels of IL-2 prior to vaccination and surgery, but only one placebo recipient with undetectable IL-2. Furthermore, nine of ten V710 recipients that had undetectable IL-17 $\alpha$ levels preoperatively died with postoperative $S$. aureus infections. Of course, IL-2 is important for the activation of T cells, including regulatory T cells (Treg) (Smigiel et al., 2014). Patients with defects in Treg have problems in maintaining immune homeostasis and develop autoimmune diseases. Other cytokines, such as Il-1 that is released during bacterial infections, can drive the conversion of Treg into Th-17 cells (Chung et al., 2009; Li et al., 2010). One hypothesis for the systemic inflammatory response syndrome seen in the vaccines might relate to an imbalance of Treg activity. While the mechanisms are unknown, these data suggest that the preoperative immune status and host response may predispose patients to death after priming of the immune system with vaccination. This provides a note of caution about vaccines directed at Th17 activation because Th17 has also been implicated in autoimmune diseases (Marwaha et al., 2012). Such a caution is implicit in the a statement about the immune response in infection in the (Smigiel et al., 2014) review: "Too much Treg cell activity can result in immunosuppression and impaired pathogen clearance, whereas too little Treg cell activity can impair effector T-cell mobilisation and avidity during infection and unleash potentially fatal inflammatory and autoimmune diseases. Identifying the cellular and molecular signals that control Treg cell homeostasis and function is essential for understanding how Treg cells influence the outcome of normal and pathological immune responses." Clearly, the model in the Fig. 1. is simply an outline of the adaptive human immune response to $S$. aureus, but a detailed and mechanistic explanation is desperately needed for the protective response in humans. Progress on the development of a safe and efficacious $S$. aureus vaccine will certainly be facilitated by investment in studies of the basic immunology of humans with $S$. aureus infections.

\section{Conclusions}

Both active and passive immunisations have been attempted, and all clinical trials have failed. These trials were based upon increased opsonophagocytic antibodies in animal models (mostly rodent) and in humans. Several more trials are ongoing, but these also are based upon opsonophagocytic antibodies, except for the rAls3p-N antigen, which focuses on Th17-mediated immunity. Previous clinical trials have used antigens (IdsB, ClfA) that stimulated the Th17 pathway and where the protection was shown to be mediated by Th17, and not antibody, have also failed to demonstrate protection (Cho et al., 2010; Joshi et al., 2012; Lin et al., 2009; Narita et al., 2010). The note of caution about active immunisation that stimulates Th17 is noted above. Similar caution applies to passive immune therapy. Anti-ClfA monoclonal antibody (tefibazumar/ Aurexis) showed a hypersensitivity reaction in one of thirty vaccine recipients (Weems et al., 2006). Development of a much needed and safe staphylococcal vaccine may require a much deeper understanding of the human immune system and the development of biomarker(s) that signify protection against staphylococci.

While prevention of infection is the ultimate goal of a staphylococcal vaccine, which will be the most difficult with biomaterial infections, we may need to accept reduced morbidity via an anti-toxin approach for the near future. Currently, decolonisation and enhanced efforts at infection control prior to surgery appear to be the best immediate answer to reducing implant infections (Allen et al., 2014; Chen et al., 2013; Colling et al., 2015; Huang et al., 2013; Kim et al., 2010; Mehta et al., 2013; Schweizer et al., 2013). The most studied drug for use in nasal decolonisation is mupirocin, but rapid emergence of plasmid-mediated resistance occurs where it is widely used, which reduces its value (Lee et al., 2013; McDanel et al., 
2013; Miller et al., 1996; Seah et al., 2012; Vivoni et al., 2005; Walker et al., 2003). Combined resistance between the topical antibiotics mupirocin and retapamulin is of great concern (McNeil et al., 2014). Newer agents such as XF73 are currently being tested in phase II trials, which have a lower propensity for development of resistance (Farrell et al., 2011). For example, retapamulin and mupirocin exhibit resistance in 3-5 passages, whereas XF-73 shows no resistance after 55 passages (Farrell et al., 2011). The lack of XF-73 resistance is perhaps due to it extremely rapid rate of killing: $>10^{5} \mathrm{~S}$. aureus killed in $15 \mathrm{~min}$ at twice the minimal inhibitor concentration (Farrell et al., 2010). Thus, while we await a much needed staphylococcal vaccine, screening, decolonisation and infection control are immediately available solutions to reduce the problem of prosthetic joint infections.

\section{Acknowledgements}

I would like to thank the University of Wisconsin electronic library system which allows emeritus professors to make full use of the libraries, without which writing this review would not have been possible.

\section{Disclosures}

I have not received any support for writing this manuscript. I retired from Merck five years ago where I was involved in some basic research studies on IdsB, which was an antigen used in the V710 vaccine trial. I was not involved in any of the clinical work on the V710 trial. I am a paid consultant for Destiny Pharma, which is developing XF-73 for nasal decolonisation.

\section{References}

Allen KB, Fowler VG Jr, Gammie JS, Hartzel JS, Onorato MT, DiNubile MJ, Sobanjo-Ter Meulen A (2014) Staphylococcus aureus infections after elective cardiothoracic surgery: observations from an international randomized placebo-controlled trial of an Investigational S. aureus vaccine. Open Forum Infect Dis 1: doi: 10.1093/ ofid/ofu071.

Aman MJ, Adhikari RP (2014) Staphylococcal bicomponent pore-forming toxins: targets for prophylaxis and immunotherapy. Toxins (Basel) 6: 950-972.

Bebbington C, Yarranton G (2008) Antibodies for the treatment of bacterial infections: current experience and future prospects. Curr Opin Biotechnol 19: 613-619.

Bestebroer J, De Haas CJ, Van Strijp JA (2010) How microorganisms avoid phagocyte attraction. FEMS Microbiol Rev 34: 395-414.

Brady RA, Mocca CP, Prabhakara R, Plaut RD, Shirtliff ME, Merkel TJ, Burns DL (2013) Evaluation of genetically inactivated alpha toxin for protection in multiple mouse models of Staphylococcus aureus infection. PLoS One 8: e63040.

Braum O, Pirzer H, Fickenscher H (2012) Interleukin-26, a highly cationic T-cell cytokine targeting epithelial cells.
Antiinflamm Antiallergy. Agents Med Chem 11: 221-229.

Casillas-Ituarte NN, Lower BH, Lamlertthon S, Fowler VG Jr, Lower SK (2012) Dissociation rate constants of human fibronectin binding to fibronectin-binding proteins on living Staphylococcus aureus isolated from clinical patients. J Biol Chem 287: 6693-6701.

Castanet J, Lacour JP, Perrin C, Brun P, Ortonne JP (1994) Juvenile pityriasis rubra pilaris associated with hypogammaglobulinaemia and furunculosis. Br J Dermatol 131: 717-719.

Chen AF, Wessel CB, Rao N (2013) Staphylococcus aureus screening and decolonization in orthopaedic surgery and reduction of surgical site infections. Clin Orthop Relat Res 471: 2383-2299.

Cho JS, Pietras EM, Garcia NC, Ramos RI, Farzam DM, Monroe HR, Magorien JE, Blauvelt A, Kolls JK, Cheung AL, Cheng G, Modlin RL, Miller LS (2010) IL-17 is essential for host defense against cutaneous Staphylococcus aureus infection in mice. J Clin Invest 120: 1762-1773.

Chung Y, Chang SH, Martinez GJ, Yang XO, Nurieva R, Kang HS, Ma L, Watowich SS, Jetten AM, Tian Q, Dong C (2009) Critical regulation of early Th17 cell differentiation by interleukin-1 signaling. Immunity $\mathbf{3 0}$ : 576-587.

Colling K, Statz C, Glover J, Banton K, Beilman G (2015) Pre-operative antiseptic shower and bath policy decreases the rate of $S$. aureus and methicillin-resistant $S$. aureus surgical site infections in patients undergoing joint arthroplasty. Surg Infect (Larchmt) 16: 124-132.

Crum-Cianflone N, Weekes J, Bavaro M (2009) Recurrent community-associated methicillin-resistant Staphylococcus aureus infections among HIV-infected persons: incidence and risk factors. AIDS Patient Care STDS 23: 499-502.

David MZ, Daum RS (2010) Community-associated methicillin-resistant Staphylococcus aureus: epidemiology and clinical consequences of an emerging epidemic. Clin Microbiol Rev 23: 616-687.

DeJonge M, Burchfield D, Bloom B, Duenas M, Walker W, Polak M, Jung E, Millard D, Schelonka R, Eyal F, Morris A, Kapik B, Roberson D, Kesler K, Patti J, Hetherington S (2007) Clinical trial of safety and efficacy of INH-A21 for the prevention of nosocomial staphylococcal bloodstream infection in premature infants. J Pediatr 151: 260-265.

Donabedian H, Gallin JI (1983) The hyperimmunoglobulin E recurrent-infection (Job's) syndrome. A review of the NIH experience and the literature. Medicine (Baltimore) 62: 195-208.

Dunne A, Ross PJ, Pospisilova E, Masin J, Meaney A, Sutton CE, Iwakura Y, Tschopp J, Sebo P, Mills KH (2010) Inflammasome activation by adenylate cyclase toxin directs Th17 responses and protection against Bordetella pertussis. J Immunol 185: 1711-1719.

Elek SD, Conen PE (1957) The virulence of Staphylococcus pyogenes for man; a study of the problems of wound infection. Br J Exp Pathol 38: 573-586.

Farrell DJ, Robbins M, Rhys-Williams W, Love WG (2010) In vitro activity of XF-73, a novel antibacterial 
agent, against antibiotic-sensitive and -resistant Grampositive and Gram-negative bacterial species. Int J Antimicrob Agents 35: 531-536.

Farrell DJ, Robbins M, Rhys-Williams W, Love WG (2011) Investigation of the potential for mutational resistance to XF-73, retapamulin, mupirocin, fusidic acid, daptomycin, and vancomycin in methicillin-resistant Staphylococcus aureus isolates during a 55-passage study. Antimicrob Agents Chemother 55: 1177-1181.

Fattom A, Matalon A, Buerkert J, Taylor K, Damaso S, Boutriau D (2015) Efficacy profile of a bivalent Staphylococcus aureus glycoconjugated vaccine in adults on hemodialysis: Phase III randomized study. Hum Vaccin Immunother 11: 632-641.

Fisher A, Webber BJ, Pawlak MT, Johnston L, Tchandja JB, Yun H (2015) Epidemiology, microbiology, and antibiotic susceptibility patterns of skin and soft tissue infections, Joint Base San Antonio-Lackland, Texas, 2012 2014. MSMR 22: 2-6.

Foster TJ, Geoghegan JA, Ganesh VK, Höök M (2014) Adhesion, invasion and evasion: the many functions of the surface proteins of Staphylococcus aureus. Nat Rev Microbiol 12: 49-62.

Fowler VG, Allen KB, Moreira ED, Moustafa M, Isgro F, Boucher HW, Corey GR, Carmeli Y, Betts R, Hartzel JS, Chan IS, McNeely TB, Kartsonis NA, Guris D, Onorato MT, Smugar SS, DiNubile MJ, Sobanjo-ter Meulen A (2013) Effect of an investigational vaccine for preventing Staphylococcus aureus infections after cardiothoracic surgery: a randomized trial. JAMA 309: 1368-1378.

Fowler VG Jr, Proctor RA (2014) Where does a Staphylococcus aureus vaccine stand? Clin Microbiol Infect 20 Suppl 5: 66-75.

Fritz SA, Tiemann KM, Hogan PG, Epplin EK, Rodriguez M, Al-Zubeidi DN, Bubeck Wardenburg J, Hunstad DA (2013) A serologic correlate of protective immunity against community-onset Staphylococcus aureus infection. Clin Infect Dis 56: 1554-1561.

Huang SS, Septimus E, Kleinman K, Moody J, Hickok J, Avery TR, Lankiewicz J, Gombosev A, Terpstra L, Hartford F, Hayden MK, Jernigan JA, Weinstein RA, Fraser VJ, Haffenreffer K, Cui E, Kaganov RE, Lolans K, Perlin JB, Platt R (2013) Targeted versus universal decolonization to prevent ICU infection. CDC Prevention Epicenters Program; AHRQ DECIDE Network and HealthcareAssociated Infections Program. New Engl J Med 368: 2255-2265.

Ishigame H, Kakuta S, Nagai T Kadoki M, Nambu A, Komiyama Y, Fujikado N, Tanahashi Y, Akitsu A, Kotaki H, Sudo K, Nakae S, Sasakawa C, Iwakura Y (2009) Differential roles of interleukin-17A and $-17 \mathrm{~F}$ in host defense against mucoepithelial bacterial infection and allergic responses. Immunity 30: 108-119.

Jansen KU, Girgenti DQ, Scully IL, Anderson AS (2013) Vaccine review: Staphylococcus aureus vaccines: problems and prospects. Vaccine 31: 2723-2230.

Joshi A, Pancari G, Cope L, Bowman EP, Cua D, Proctor RA, McNeely T (2012) Immunization with Staphylococcus aureus iron regulated surface determinant B (IsdB) confers protection via Th17/IL17 pathway in a murine sepsis model. Hum Vaccin Immunother 8: 336-346.
Kapadia BH, Berg RA, Daley JA, Fritz J, Bhave A, Mont MA (2015) Periprosthetic joint infection. Lancet, doi: 10.1016/S0140-6736(14)61798-0.

Kim DH, Spencer M, Davidson SM, Li L, Shaw JD, Gulczynski D, Hunter DJ, Martha JF, Miley GB, Parazin SJ, Dejoie P, Richmond JC (2010) Institutional prescreening for detection and eradication of methicillinresistant Staphylococcus aureus in patients undergoing elective orthopaedic surgery. J Bone Joint Surg Am 92: 1820-1826.

Klevens RM, Morrison MA, Nadle J, Petit S, Gershman K, Ray S, Harrison LH, Lynfield R, Dumyati G, Townes JM, Craig AS, Zell ER, Fosheim GE, McDougal LK, Carey RB, Fridkin SK; Active Bacterial Core surveillance (ABCs) MRSA Investigators (2007) Invasive methicillin-resistant Staphylococcus aureus infections in the United States. JAMA 298: 1763-1771.

Kobayashi SD, Braughton KR, Palazzolo-Ballance AM, Kennedy AD, Sampaio E, Kristosturyan E, Whitney AR, Sturdevant DE, Dorward DW, Holland SM, Kreiswirth BN, Musser JM, DeLeo FR (2010) Rapid neutrophil destruction following phagocytosis of Staphylococcus aureus. J Innate Immun 2: 560-575.

Kolata JB, Kühbandner I, Link C, Normann N, Vu CH, Steil L, Weidenmaier C, Bröker BM (2015) The fall of a dogma? Unexpected high T-cell memory response to Staphylococcus aureus in humans. J Infect Dis 212: 830838.

Laabei M, Uhlemann AC, Lowy FD, Austin ED, Yokoyama M, Ouadi K, Feil E, Thorpe HA, Williams B, Perkins M, Peacock SJ, Clarke SR, Dordel J, Holden M, Votintseva AA, Bowden R, Crook DW, Young BC, Wilson DJ, Recker M, Massey RC (2015) Evolutionary trade-offs underlie the multi-faceted virulence of Staphylococcus aureus. PLoS Biol 13: e1002229.

Lavine JS, Bjørnstad ON, de Blasio BF, Storsaeter (2012) Short-lived immunity against pertussis, age-specific routes of transmission, and the utility of a teenage booster vaccine. Vaccine 30: 544-551.

Lee H, Lim H, Bae IK, Yong D, Jeong SH, Lee K, Chong Y (2013) Coexistence of mupirocin and antiseptic resistance in methicillin-resistant Staphylococcus aureus isolates from Korea. Diagn Microbiol Infect Dis 75: 308312.

Li L, Kim J, Boussiotis VA (2010) IL-1 beta-mediated signals preferentially drive conversion of regulatory $\mathrm{T}$ cells but not conventional T cells into IL-17-producing cells. J Immunol 185: 4148-4153.

Lin WT, Wu CD, Cheng SC, Chiu CC, Tseng CC, Chan HT, Chen PY, Chao CM (2015) High prevalence of methicillin-resistant Staphylococcus aureus among patients with septic arthritis caused by Staphylococcus aureus. PLoS One 10: e0127150.

Lin L, Ibrahim AS, Xu X, Farber JM, Avanesian V, Baquir B, Fu Y, French SW, Edwards JE Jr, Spellberg B (2009) Th1-Th17 cells mediate protective adaptive immunity against Staphylococcus aureus and Candida albicans infection in mice. PLoS Pathog 5: e1000703.

Liu C, Graber CJ, Karr M, Diep BA, Basuino L, Schwartz BS, Enright MC, O'Hanlon SJ, Thomas JC, Perdreau-Remington F, Gordon S, Gunthorpe H, Jacobs 
R, Jensen P, Leoung G, Rumack JS, Chambers HF (2008) A population-based study of the incidence and molecular epidemiology of methicillin-resistant Staphylococcus aureus disease in San Francisco, 2004-2005. Clin Infect Dis 46: 1637-1646.

Lower SK, Lamlertthon S, Casillas-Ituarte NN, Lins RD, Yongsunthon R, Taylor ES, DiBartola AC, Edmonson C, McIntyre LM, Reller LB, Que YA, Ros R, Lower BH, Fowler VG Jr (2011) Polymorphisms in fibronectin binding protein A of Staphylococcus aureus are associated with infection of cardiovascular devices. Proc Natl Acad Sci U S A 108: 18372-18377.

Lowy FD (1998) Staphylococcus aureus infections. N Engl J Med 339: 520-532.

Lu T, Porter AR, Kennedy AD, Kobayashi SD, DeLeo FR (2014) Phagocytosis and killing of Staphylococcus aureus by human neutrophils. J Innate Immun 6: 639-649.

Ma CS, Chew GY, Simpson N, Priyadarshi A, Wong M, Grimbacher B, Fulcher DA, Tangye SG, Cook MC (2008) Deficiency of Th17 cells in hyper IgE syndrome due to mutations in STAT3. J Exp Med 205: 1551-1557.

Maródi L, Cypowyj S, Tóth B, Chernyshova L, Puel A, Casanova JL (2012) Molecular mechanisms of mucocutaneous immunity against Candida and Staphylococcus species. J Allergy Clin Immunol 130: 1019-1027.

Marwaha AK, Leung NJ, McMurchy AN, Levings MK (2012) Th17 cells in autoimmunity and immunodeficiency: Protective or Pathogenic? Front Immunol 3: 1-8.

McCarthy H, Rudkin JK, Black NS, Gallagher L, O'Neill E, O'Gara JP (2015) Methicillin resistance and the biofilm phenotype in Staphylococcus aureus. Front Cell Infect Microbiol 5: 1. doi: 10.3389/fcimb.2015.00001

McDanel JS, Murphy CR, Diekema DJ, Quan V, Kim DS, Peterson EM, Evans KD, Tan GL, Hayden MK, Huang SS (2013) Chlorhexidine and mupirocin susceptibilities of methicillin-resistant Staphylococcus aureus from colonized nursing home residents. Antimicrob Agents Chemother 57: 552-558.

McGirr A, Fisman DN (2015) Duration of pertussis immunity after DTaP immunization: a meta-analysis. Pediatrics 135: 331-343.

McNeely TB, Shah NA, Fridman A, Joshi A, Hartzel JS, Keshari RS, Lupu F, DiNubile MJ (2014) Mortality among recipients of the Merck V710 Staphylococcus aureus vaccine after postoperative $S$. aureus infections: an analysis of possible contributing host factors. Hum Vaccin Immunother 10: 3513-3516.

McNeil JC, Hulten KG, Kaplan SL, Mason EO (2014) Decreased susceptibilities to Retapamulin, Mupirocin, and Chlorhexidine among Staphylococcus aureus isolates causing skin and soft tissue infections in otherwise healthy children. Antimicrob Agents Chemother 58: 2878-2883.

Mehta S, Hadley S, Hutzler L, Slover J, Phillips M, Bosco JA 3rd. Impact of preoperative MRSA screening and decolonization on hospital-acquired MRSA burden (2013) Clin Orthop Relat Res 471: 2367-2371. (see erratum in Clin Orthop Relat Res 471: 2044, 2013)

Meller S, Di Domizio J, Voo KS, Friedrich HC, Chamilos G, Ganguly D, Conrad C, Gregorio J, Le Roy D, Roger T, Ladbury JE, Homey B, Watowich S, Modlin, RL
Kontoyiannis DP, Liu YJ, Arold ST, Gilliet M (2015) T 17 cells promote microbial killing and innate immune sensing of DNA via interleukin 26. Nat Immunol 16: 970-979.

Millar EV, O’Brien KL, Watt JP, Lingappa J, Pallipamu R, Rosenstein N, Hu D, Reid R, Santosham M (2005) Epidemiology of invasive Haemophilus influenzae type A disease among Navajo and White Mountain Apache children, 1988-2003. Clin Infect Dis 40: 823-830.

Miller MA, Dascal A, Portnoy J, Mendelson J (1996) Development of mupirocin resistance among methicillinresistant Staphylococcus aureus after widespread use of nasal mupirocin ointment. Infect Control Hosp Epidemiol 17: 811-813.

Minegishi Y, Saito M, Nagasawa M Takada H, Hara T, Tsuchiya S, Agematsu K, Yamada M, Kawamura N, Ariga T, Tsuge I, Karasuyama H (2009) Molecular explanation for the contradiction between systemic Th17 defect and localized bacterial infection in hyper-IgE syndrome. J Exp Med 206: 1291-1301.

Misstear K, McNeela EA, Murphy AG, Geoghegan JA, O'Keeffe KM, Fox J, Chan K, Heuking S, Collin N, Foster TJ, McLoughlin RM, Lavelle EC (2014) Targeted nasal vaccination provides antibody-independent protection against Staphylococcus aureus. J Infect Dis 209: 14791484.

Montgomery CP, Daniels M, Zhao F, Alegre ML, Chong AS, Daum RS (2014) Protective immunity against recurrent Staphylococcus aureus skin infection requires antibody and interleukin-17A. Infect Immun 82: 2125 2134.

Montgomery CP, David MZ, Daum RS (2015) Host factors that contribute to recurrent staphylococcal skin infection. Curr Opin Infect Dis 28: 253-258.

Montanaro L, Speziale P, Campoccia D, Ravaioli S, Cangini I, Pietrocola G, Giannini S, Arciola CR (2011) Scenery of Staphylococcus implant infections in orthopedics. Future Microbiol 6: 1329-1349.

Morrison-Rodriguez SM, Pacha LA, Patrick JE, Jordan NN (2010) Community-associated methicillin-resistant Staphylococcus aureus infections at an army training installation. Epidemiol Infect 138: 721-729.

Narita K, Hu DL, Mori F, Wakabayashi K, Iwakura Y, Nakane A (2010) Role of interleukin-17A in cell-mediated protection against Staphylococcus aureus infection in mice immunized with the fibrinogen-binding domain of clumping factor A. Infect Immun 78: 4234-4242.

Nissen M, Marshall H, Richmond P, Shakib S, Jiang Q, Cooper D, Rill D, Baber J, Eiden J, Gruber W, Jansen KU, Emini EA, Anderson AS, Zito ET, Girgenti D (2015) A randomized phase I study of the safety and immunogenicity of three ascending dose levels of a 3-antigen Staphylococcus aureus vaccine (SA3Ag) in healthy adults. Vaccine 33: 1846-1854.

O'Keeffe KM, Wilk MM, Leech JM, Murphy AG, Laabei M, Monk IR, Massey RC, Lindsay JA, Foster TJ, Geoghegan JA, McLoughlin RM (2015) Manipulation of autophagy in phagocytes facilitates Staphylococcus aureus bloodstream infection. Infect Immun 83: 3445-3457.

Olsen K, Falch BM, Danielsen K, Johannessen M, Ericson Sollid JU, Thune I, Grimnes G, Jorde R, Simonsen GS, Furberg AS (2012) Staphylococcus aureus nasal 
carriage is associated with serum 25-hydroxyvitamin D levels, gender and smoking status. The Tromsø Staph and Skin Study. Eur J Clin Microbiol Infect Dis 31: 465-473.

Pancari G, Fan H, Smith S, Joshi A, Haimbach R, Clark D, Li Y, Hua J, McKelvey T, Ou Y, Drummond J, Cope L, Montgomery D, McNeely T (2012) Characterization of the mechanism of protection mediated by CS-D7, a monoclonal antibody to Staphylococcus aureus iron regulated surface determinant B (IsdB). Front Cell Infect Microbiol 20:36. eCollection 2012.

Parvizi J, Alijanipour P, Barberi EF, Hickok NJ, Phillips KS, Shapiro IM, Schwarz EM, Stevens MH, Wang Y, Shirtliff ME (2015) Novel developments in the prevention, diagnosis, and treatment of periprosthetic joint infections. J Am Acad Orthop Surg 23 Suppl: S32-S43.

Pauli NT, Kim HK, Falugi F, Huang M, Dulac J, Henry Dunand C, Zheng NY, Kaur K, Andrews SF, Huang Y, DeDent A, Frank KM, Charnot-Katsikas A, Schneewind O, Wilson PC (2014) Staphylococcus aureus infection induces protein A-mediated immune evasion in humans. J Exp Med 211: 2331-2339.

Pozzi C, Lofano G, Mancini F, Soldaini E, Speziale P, De Gregorio E, Rappuoli R, Bertholet S, Grandi G, Bagnoli F (2015) Phagocyte subsets and lymphocyte clonal deletion behind ineffective immune response to Staphylococcus aureus. FEMS Microbiol Rev 39: 750-763.

Proctor RA(2012a) Is there a future for a Staphylococcus aureus vaccine? Vaccine 30: 2921-2927.

Proctor RA (2012b) Challenges for a universal Staphylococcus aureus vaccine. Clin Infect Dis 54: 11791186.

Provenza G, Provenzano M, Visai L, Burke FM, Geoghegan JA, Stravalaci M, Gobbi M, Mazzini G, Arciola CR, Foster TJ, Speziale P (2010) Functional analysis of a murine monoclonal antibody against the repetitive region of the fibronectin-binding adhesins fibronectinbinding protein A and fibronectin-binding protein B from Staphylococcus aureus. FEBS J 277: 4490-4505.

Puel A, Picard C, Lorrot M, Pons C, Chrabieh M, Lorenzo L, Mamani-Matsuda M, Jouanguy E, Gendrel D, Casanova JL (2008) Recurrent staphylococcal cellulitis and subcutaneous abscesses in a child with autoantibodies against IL-6. J Immunol 180: 647-654.

Quilty S, Kwok G, Hajkowicz K, Currie B (2009) High incidence of methicillin-resistant Staphylococcus aureus sepsis and death in patients with febrile neutropenia at Royal Darwin Hospital. Intern Med J 39: 557-559.

Rasigade JP, Sicot N, Laurent F, Lina G, Vandenesch F, Etienne J (2011) A history of Panton-Valentine leukocidin (PVL)-associated infection protects against death in PVLassociated pneumonia. Vaccine 29: 4185-4186.

Rose WE, Eickhoff JC, Shukla SK, Pantrangi M, Rooijakkers S, Cosgrove SE, Nizet V, Sakoulas G (2012) Elevated serum interleukin-10 at time of hospital admission is predictive of mortality in patients with Staphylococcus aureus bacteremia. J Infect Dis 206: 1604-1611.

Ross CL, Liang X, Liu Q, Murray BE, Höök M, Ganesh VK (2012) Targeted protein engineering provides insights into binding mechanism and affinities of bacterial collagen adhesins. J Biol Chem 287: 34856-34865.
Rupp ME, Holley HP, Jr, Lutz J, Dicpinigaitis PV, Woods CW, Levine DP, Veney N, Fowler VG, Jr (2007) Phase II, randomized, multicenter, double-blind, placebocontrolled trial of a polyclonal anti-Staphylococcus aureus capsular polysaccharide immune globulin in treatment of Staphylococcus aureus bacteremia. Antimicrob Agents Chemother 51: 4249-4254.

Salgado-Pabón W, Schlievert PM (2014) Models matter: the search for an effective Staphylococcus aureus vaccine. Nat Rev Microbiol 12: 585-591.

Schmidt CS, White CJ, Ibrahim AS, Filler SG, Fu Y, Yeaman MR, Edwards JE Jr, Hennessey JP Jr (2012) NDV3 , a recombinant alum-adjuvanted vaccine for Candida and Staphylococcus aureus, is safe and immunogenic in healthy adults. Vaccine 30: 7594-7600.

Schreiner J, Kretschmer D, Klenk J, Otto M, Bühring HJ, Stevanovic S, Wang JM, Beer-Hammer S, Peschel A, Autenrieth SE (2013) Staphylococcus aureus phenolsoluble modulin peptides modulate dendritic cell functions and increase in vitro priming of regulatory $\mathrm{T}$ cells. $\mathrm{J}$ Immunol 190: 3417-3426.

Schweizer M, Perencevich E, McDanel J, Carson J, Formanek M, Hafner J, Braun B, Herwaldt L (2013) Effectiveness of a bundled intervention of decolonization and prophylaxis to decrease Gram positive surgical site infections after cardiac or orthopedic surgery: systematic review and meta-analysis. BMJ 346: doi: 10.1136/bmj. f2743.

Seah C, Alexander DC, Louie L, Simor A, Low DE, Longtin J, Melano RG (2012) MupB, a new high-level mupirocin resistance mechanism in Staphylococcus aureus. Antimicrob Agents Chemother 56: 1916-1920.

Seok, J, Warren HS, Cuenca AG, Mindrinos MN, Baker HV, Xu W, Richards DR, McDonald-Smith GP, Gao H, Hennessy L, Finnerty CC, López CM, Honari S, Moore EE, Minei JP, Cuschieri J, Bankey PE, Johnson JL, Sperry J, Nathens AB, Billiar TR, West MA, Jeschke MG, Klein MB, Gamelli RL, Gibran NS, Brownstein BH, Miller-Graziano C, Calvano SE, Mason PH, Cobb JP, Rahme LG, Lowry SF, Maier RV, Moldawer LL, Herndon DN, Davis RW, Xiao W, Tompkins RG; Inflammation and Host Response to injury, Large Scale Collaborative Research Program (2013) Genomic responses in mouse models poorly mimic human inflammatory diseases. Proc Natl Acad Sci USA 110: $3507-3512$.

Serruto D, Rappuoli R, Scarselli M, Gros P, van Strijp JA (2010) Molecular mechanisms of complement evasion: learning from staphylococci and meningococci. Nat Rev Microbiol 8: 393-399.

Shinefield H, Black S, Fattom A, Horwith G, Rasgon S, Ordonez J, Yeoh H, Law D, Robbins JB, Schneerson R, Muenz L, Fuller S, Johnson J, Fireman B, Alcorn H, Naso R (2002) Use of a Staphylococcus aureus conjugate vaccine in patients receiving hemodialysis. N Engl J Med 346: 491-496.

Shvili D, David M, Mimouni M(1987) Childhood onset pityriasis rubra pilaris with immunologic abnormalities. Pediatr Dermatol 4: 21-23.

Smigiel KS, Srivastava S, Stolley JM, Campbell DJ (2014) Regulatory T-cell homeostasis: steady-state 
maintenance and modulation during inflammation. Immunol Rev 259: 40-59.

Spaan AN, Surewaard BG, Nijland R, van Strijp JA (2013) Neutrophils versus Staphylococcus aureus: A biological tug of war. Annu Rev Microbiol 67: 629-650.

Spaulding AR, Lin YC, Merriman JA, Brosnahan AJ, Peterson ML, Schlievert PM (2012) Immunity to Staphylococcus aureus secreted proteins protects rabbits from serious illnesses. Vaccine 30: 5099-5109.

Spellberg B, Ibrahim AS, Yeaman MR, Lin L, Fu Y, Avanesian V, Bayer AS, Filler SG, Lipke P, Otoo H, Edwards JE Jr (2008) The antifungal vaccine derived from the recombinant $\mathrm{N}$ terminus of Als3 protects mice against the bacterium Staphylococcus aureus. Infect Immun 76: 4574-4580.

Tkaczyk C, Hua L, Varkey R, Shi Y, Dettinger L, Woods R, Barnes A, MacGill RS, Wilson S, Chowdhury P, Stover CK, Sellman BR (2012) Identification of antialpha toxin monoclonal antibodies that reduce the severity of Staphylococcus aureus dermonecrosis and exhibit a correlation between affinity and potency. Clin Vaccine Immunol 19: 377-385.

Thomason J, Rentsch C, Stenehjem EA, Hidron AI, Rimland D (2015) Association between vitamin D deficiency and methicillin-resistant Staphylococcus aureus infection. Infection, 43: 715-722.

Tong SY, Davis JS, Eichenberger E, Holland TL, Fowler VG Jr (2015) Staphylococcus aureus infections: epidemiology, pathophysiology, clinical manifestations, and management. Clin Microbiol Rev 28: 603-661.

Van der Does AM, Kenne E, Koppelaar E, Agerberth B, Lindbom L (2014) Vitamin $\mathrm{D}_{3}$ and phenylbutyrate promote development of a human dendritic cell subset displaying enhanced antimicrobial properties. J Leukoc Biol 95: 883891.

van Dissel JT, van Langevelde P, Westendorp RG, Kwappenberg K, Frölich M (1998) Anti-inflammatory cytokine profile and mortality in febrile patients. Lancet 351: 950-953.

van Kessel KP, Bestebroer J, van Strijp JA (2014) Neutrophil-Mediated Phagocytosis of Staphylococcus aureus. Front Immunol 5: 467.

Varrone JJ, de Mesy Bentley KL, Bello-Irizarry SN, Nishitani K, Mack S, Hunter JG, Kates SL, Daiss JL, Schwarz EM (2014) Passive immunization with anti-glucosaminidase monoclonal antibodies protects mice from implant-associated osteomyelitis by mediating opsonophagocytosis of Staphylococcus aureus megaclusters. J Orthop Res 32: 1389-1396.

Verkaik NJ, Lebon A, de Vogel CP, Hooijkaas H, Verbrugh HA, Jaddoe VW, Hofman A, Moll HA, van Belkum A, van Wamel WJ (2010) Induction of antibodies by Staphylococcus aureus nasal colonization in young children. Clin Microbiol Infect 16: 1312-1317.

Vivoni AM, Santos KR, de-Oliveira MP, GiambiagideMarval M, Ferreira AL, Riley LW, Moreira BM (2005) Mupirocin for controlling methicillin-resistant Staphylococcus aureus: lessons from a decade of use at a university hospital. Infect Control Hosp Epidemiol 26: 662-667.
Walker ES, Vasquez JE, Dula R, Bullock H, Sarubbi FA (2003) Mupirocin-resistant, methicillin-resistant Staphylococcus aureus: does mupirocin remain effective? Infect Control Hosp Epidemiol 24: 342-346.

Wang JW, Hogan PG, Hunstad DA, Fritz SA (2015) Vitamin D sufficiency and Staphylococcus aureus infection in children. Pediatr Infect Dis J 34: 544-555.

Weems J, Steinberg J, Filler S, Baddley JW, Corey GR, Sampathkumar P, Winston L, John JF, Kubin CJ, Talwani R, Moore T, Patti JM, Hetherington S, Texter M, Wenzel E, Kelley VA, Fowler VG Jr (2006) Veronate human polyclonal IgG with high anti-S. aureus and antipolyclonal antibodies tested in neonates. Antimicrob Agents Chemother 50: 2751-2755.

White CJ, Gallin JI (1986) Phagocyte defects. Clin Immunol Immunopathol 40: 50-61.

Yan L, Zhang L, Ma H, Chiu D, Bryers JD (2014) A single B-repeat of Staphylococcus epidermidis accumulation-associated protein induces protective immune responses in an experimental biomaterialassociated infection mouse model. Clin Vaccine Immunol 21: 1206-1214.

\section{Web references}

Clinical Trials. Gov: https://clinicaltrials.gov/ct2/results? term=staphylococcus \&Search=Search

GSK Pipeline Report, March 2015: http://www.gsk.com/ en-gb/research/what-we-are-working-on/product-pipeline/

\section{Discussion with Reviewer}

Reviewer I: The author's thesis that the greatest challenge in developing a protective vaccine is that " $S$. aureus is part of the normal human flora" is accepted. However, from a practical standpoint, an equal challenge is that $S$. aureus infection rates are too low for the clinical research needed to discover biomarkers of protective immunity. This challenge deserves some attention, perhaps by citing the well document $\sim 1 \%$ surgical site infection rates in total joint replacement and heart valve replacement.

Authors: The development of biomarkers is not dependent upon the infection rates, as one can search for biomarkers in patients with bona fide infections. For example, in a series of patients with $S$. aureus bacteraemia, some cytokines (high TNF-a, high IL-6, and low IL10) have been found to be markers for higher mortality (Rose $\mathrm{W}$ et al., 2012). However, the number of subjects and the need for a large prospective trials to define these as biomarkers for severe disease are still needed. Therefore, even if only $1 \%$ of surgical site infections were studied, presence of a cytokine or particular lymphocyte subset that correlated with cure would indicate protective immunity, and it could be found in $90 \%$ of the $1 \%$ of patients. Of course, I do not share the view that the infection rates are low as $S$. aureus bacteraemia is the number one cause of bacteraemia in people over 65 years old, the number one cause of children 
being admitted to hospitals, and the number one cause of children having surgery. Therefore, there are plenty of cases for the study of $S$. aureus infections.

Reviewer II: Biomarkers in rodent models of $S$. aureus infections but also well-known biomarkers for $H$. influenzae and S. pneumonia infections in humans, have either no effect or can even have an adverse effect in $S$. aureus infections in humans. Where to your opinion do we need to look for biomarkers that will solve this problem? Authors: We need to look to human disease responses for biomarkers. There is already human data for anti-toxin antibodies being protective against toxic shock syndrome and there are clinical trials underway examining the value of anti-alpha toxin antibodies in human disease. These antibodies are most likely to reduce disease severity. Of note, animal models and human responses are parallel, suggesting that these models will be predictive of human outcomes. Where we lack biomarkers are for disease prevention. Because animal models have performed so poorly (high levels of protection in animal models and failure to protect in human vaccine trails), one will need to look to human studies for the discovery and vetting of biomarkers.
Reviewer III: Considering the obvious challenges in developing vaccines for $S$. aureus, as outlined in the review, should we revise downwards our expectation for a successful vaccine in this context? For example, should we accept that a reduction in severity of infection be the target goal? With this in mind, would any of the current "failed" vaccines satisfy such reduced criteria?

Authors: I agree that we should revise our expectations for a successful vaccine, wherein reduction of disease severity would be the goal. Presumably, this might produce fewer ICU admissions, shorter time in ICU, shorter hospital stays, and reduced hospital costs. Clearly, these would be highly desired outcomes. To date, none of the clinical trials has been designed to examine these outcomes, but none of the clinical trials found evidence for this, except for the use of Anti-ClfA monoclonal antibodies (tefibazumab = Aurexis by Inhibitex) as passive immunisation for S. aureus bacteraemia in a phase 2 trial showed decreased relapses and complications of the infection. Unfortunately, there was no reduced mortality and hypersensitivity developed in 1 of 30 patients (Weems et al.). Two other trials using ClfA as an antigen have not been reported to show this result.

Editor's Note: Scientific Editor in charge of the paper: R. Geoff Richards. 